\title{
IL-8 Is Associated with Non-Viremic State and IFN- $\gamma$ with Biochemical Activity in HCV-Seropositive Blood Donors
}

\author{
Maria Alice S. Zarife ${ }^{a}$ b Eliana A.G. Reis ${ }^{a} \quad G^{a}$ den C. Meira ${ }^{d}$ \\ Theomira M.A. Carmo ${ }^{a}$ Gisele B. Lopes ${ }^{a}$ Emilia C.O.B. Malafaia ${ }^{a}$ \\ Helder R. Silva ${ }^{a}$ Nelma Santana ${ }^{c}$ Olindo A. Martins-Filho ${ }^{d}$ Mitermayer G. Reis ${ }^{a}$

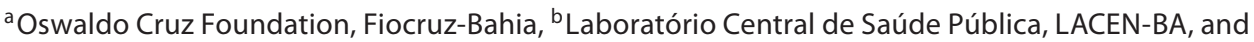 \\ 'HEMOBA, Salvador, and d Centro de Pesquisas René Rachou, Fiocruz-Minas, Belo Horizonte, Brazil
}

\section{Key Words}

Hepatitis $C$ virus - Blood donors - Cytokines, inflammatory and regulatory $\cdot$ Serological status $\cdot$ Virological status .

Alanine aminotransferase

\begin{abstract}
Objective: The aim of this study was to explore a possible association between the pattern of serum cytokines with the virological and biochemical status of hepatitis C virus (HCV)seropositive blood donors. Methods: 23 non-viremic and 33 viremic HCV-seropositive blood donors based on HCV-RNA tests, and 29 healthy individuals were included. Cytometric bead array assays were performed to detect cytokines. $\boldsymbol{R e}$ sults: The subjects were classified as low, medium or high cytokine producers based on the tertile distribution. The absence of detectable viremia was associated with high IL-1 $\beta$ and IL-8 producers. Conversely, elevated levels of IL-6, IL-10 and IL-12 were associated with detectable viremia. An increased frequency of high IL-1 $\beta$ producers was observed frequently in the non-viremic recombinant immunoblot assay (RIBA)-indeterminate subjects, while the high IL-4, IL-6, IL-8, IL-10 and IL-12 producers were more frequent in the non-viremic RIBA-positive subjects. Furthermore, the levels of IL-1 $\beta$
\end{abstract}

and IL-8 were higher in viremic subjects with a low level of alanine-aminotransferase (ALT), whereas the level of IFN- $\gamma$ was increased among viremic subjects with a high ALT level. Conclusion: IL-1 $\beta$ and IL-8 were more likely to be associated with a non-viremic or less severe HCV infection, whereas IL-2 and IFN- $\gamma$ levels correlated with a high ALT level.

Copyright $\odot 2010$ S. Karger AG, Basel

\section{Introduction}

Hepatitis $\mathrm{C}$ virus (HCV) infection is an important global public health problem, affecting some 130 million people worldwide [1]. HCV induces a chronic infection in $50-80 \%$ of infected individuals, and chronic HCV infection has been linked with cirrhosis and hepatocellular carcinoma [2-4].

Approximately $20 \%$ of $\mathrm{HCV}$-infected individuals spontaneously eliminate the virus early during infection, whereas a majority of individuals $(\sim 80 \%)$ become chronically infected. These chronically infected individuals represent a challenge for the medical and scientific community. The prognostic factors responsible for the spontaneous resolution, as well as an understanding of early

\section{KARGER}

Fax +4161306 1234 E-Mail karger@karger.ch www.karger.com
(ㄷ) 2010 S. Karger AG, Basel

0300-5526/11/0542-0087\$38.00/0

Accessible online at:

www.karger.com/int
Dr. Mitermayer G. Reis

Fundação Oswaldo Cruz, Rua Waldemar Falcão

121, Candeal

Salvador, BA 40296-710 (Brazil)

Tel. +55 713176 2203, Fax +55 713176 2326, E-Mail miter@bahia.fiocruz.br 
Table 1. Study population

\begin{tabular}{|c|c|c|c|}
\hline \multirow[t]{2}{*}{ Parameter } & \multicolumn{3}{|l|}{ Groups } \\
\hline & $\begin{array}{l}\text { healthy } \\
(\mathrm{n}=39), \mathrm{n}\end{array}$ & $\begin{array}{l}\text { non-viremic } \\
(\mathrm{n}=23), \mathrm{n}\end{array}$ & $\begin{array}{l}\text { viremic } \\
(\mathrm{n}=33), \mathrm{n}\end{array}$ \\
\hline Age range, years & $19-56$ & $19-51$ & $19-56$ \\
\hline Male gender, $\mathrm{n}$ & $34(87.2 \%)$ & $15(65.2 \%)$ & $22(72.7 \%)$ \\
\hline \multicolumn{4}{|c|}{ HCV-RNA genotypes } \\
\hline 1 & NA & NA & $28(84.85 \%)$ \\
\hline 2 & NA & NA & $1(3.3 \%)$ \\
\hline 3 & NA & NA & $4(12.12 \%)$ \\
\hline
\end{tabular}

characteristics responsible for viral clearance or persistence, are still unknown. It is unclear why the immune system is so inefficient in eliminating the virus even though both humoral and cellular immune responses are induced [5]. However, the balance of proinflammatory and regulatory cytokines appears to be important in determining the course of $\mathrm{HCV}$ infection. An early and strong proinflammatory immune response against $\mathrm{HCV}$ seems to play an important role in disease resolution [6]. However, it has been suggested that a strong proinflammatory cytokine response could play an important role in the development of hepatic injury in patients with chronic hepatitis $\mathrm{C}$, and therefore, apart from contributing to viral clearance, this polarized immunological profile may contribute to the pathogenesis of liver disease. Subjects with a self-limiting HCV infection appear to maintain their ability to mount both an inflammatory and a regulatory cytokine response for extended periods following viral clearance [7].

The aim of this study was to explore a possible association between the pattern of serum cytokines and the immunological, virological and biochemical status of $\mathrm{HCV}$-seropositive blood donors. Our findings suggest new elements that point to distinct cy tokine patterns that are associated with a specific serological and virological status and may be applied as a prognostic laboratory indicator for the natural course of $\mathrm{HCV}$ infection.

\section{Materials and Methods}

\section{Samples}

Fifty-six blood donors who were screened for HCV infection at the Hematology and Hemotherapy Foundation (HEMOBA), Salvador, Brazil, were invited to participate in this study. The protocol was approved by the Institutional Ethics Committee and informed consent was obtained from each individual. All volunteers with a positive diagnosis were clinically evaluated at the Edgard Santos Hospital-Federal University of Bahia, Brazil. Blood samples were collected from each individual in a $10-\mathrm{ml}$ Vacutainer tube without anticoagulant (Becton Dickinson, San Jose, Calif., USA). Serum aliquots were separated for serological and molecular analysis and stored at $-70^{\circ}$ until tested for cytokine levels. All sera were screened for anti-HCV antibody using an automated thirdgeneration enzyme immunoassay (EIA; MEIA, System AXSYM, Abbott Diagnostics, Wiesbaden, Germany). A supplemental recombinant immunoblot assay (RIBA 3.0; Chiron, Emeryville, Calif., USA) was performed to confirm all EIA positives. HCV-seropositive subjects were segregated into 2 groups: (1) non-viremic (anti-HCV-positive and undetectable HCV-RNA, $\mathrm{n}=23$ ), and (2) viremic (anti-HCV-positive and detectable HCV-RNA, $\mathrm{n}=33$ ). All viremic groups were genotyped: type 1 (84.85\%), type 2 (3.03\%), and type 3 (12.12\%). Healthy individuals (anti-HCV-negative and undetectable HCV-RNA, $\mathrm{n}=39$ ) were included as control subjects. The age range in the non-viremic, viremic and control groups was $19-51$ (65.2\% male), $19-56$ (72.7\% male) and $19-56$ years $(87.2 \%$ male), respectively (table 1). The non-viremic group was further classified into 2 subgroups based on the RIBA profile: RIBA-indeterminate (RIBA-IND, $\mathrm{n}=15$ ), and RIBA-positive (RIBA-POS, $\mathrm{n}=7$ ). The viremic group was classified into 2 distinct subgroups: low and high viral load $(n=7)$ or low and high alanine aminotransferase (ALT, $\mathrm{n}=10$ ) using the median viral load of $369,000 \mathrm{IU} / \mathrm{ml}$ and median ALT level (46 IU/ml) as the cutoffs for each group. The non-viremic group most likely included individuals with a previous HCV infection or whose HCV-RNA was temporarily undetectable due to transient partial control of viral replication before the infection became chronic [8]. The viremic group likely represented acute/chronic HCV-infected individuals [9].

\section{Molecular Analysis}

HCV-RNA was extracted from $200 \mu \mathrm{l}$ serum using the Amplicor RT-PCR system (Roche, Branchberg, N.J., USA) that has a sensitivity of $50 \mathrm{IU} / \mathrm{ml}$. The samples with detectable HCV-RNA were further genotyped (table 1) using an in-house nested RT-PCR and RFLP assay [10].

\section{Cytometric Bead Array Assay}

The cytometric bead array (CBA) kit (Becton Dickinson Biosciences Pharmingen, San Diego, Calif., USA) was used for quantitative analysis of serum cytokines, following the manufacturer's instructions and as previously described [11]. Briefly, a mixture of beads specific for the human Th1/Th2 cytokines (IL-2, IL-4, IL-5, IL-10, IFN- $\gamma$ and TNF- $\alpha$ ) or inflammatory cytokines (IL-12, TNF- $\alpha$, IL-10, IL-6, IL-1 $\beta$ and IL-8) with distinct fluorescent intensities (in the FL-3 channel) were coated with capture antibodies specific for each cytokine. A second fluorescently labeled anticytokine antibody was added and the concentration of the individual cytokines was indicated by their fluorescent intensity. Data were acquired using a FACScalibur flow cytometer (Becton Dickinson). CellQuest software was used for sample analysis, and the data were formatted using the BD CBA software. The results were based on a standard concentration curve.

Statistical Analysis

Statistical analysis was performed using GraphPad Prism Version 5.1 (GraphPad Software Inc., La Jolla, Calif., USA). The $\chi^{2}$ 


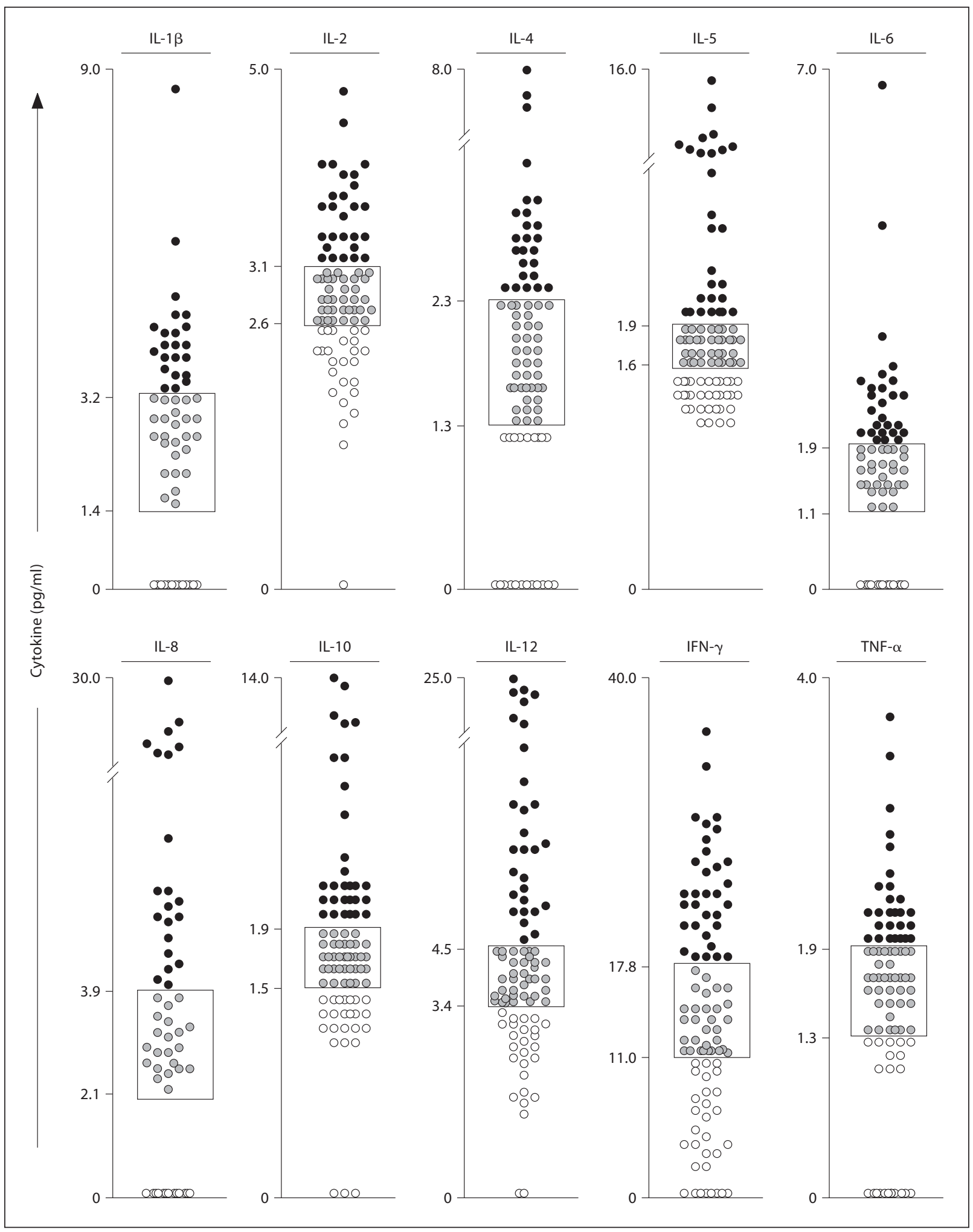

Fig. 1. Serum cytokine concentration from non-viremic, viremic and healthy blood donors was used to classify the subjects as low $(\bigcirc)$, medium $(\bigcirc)$ and high $(\bullet)$ cytokine producers based on the stratification of the cytokine level into tertiles. Quantitative cyto- kine measurements were performed by CBA assay for IL-1 $\beta$, IL-2, IL-4, IL-5, IL-6, IL-8, IL-10, IL-12, IFN- $\gamma$ and TNF- $\alpha$. The cutoff values for each cytokine are presented in the boxes representing the middle tertile. 


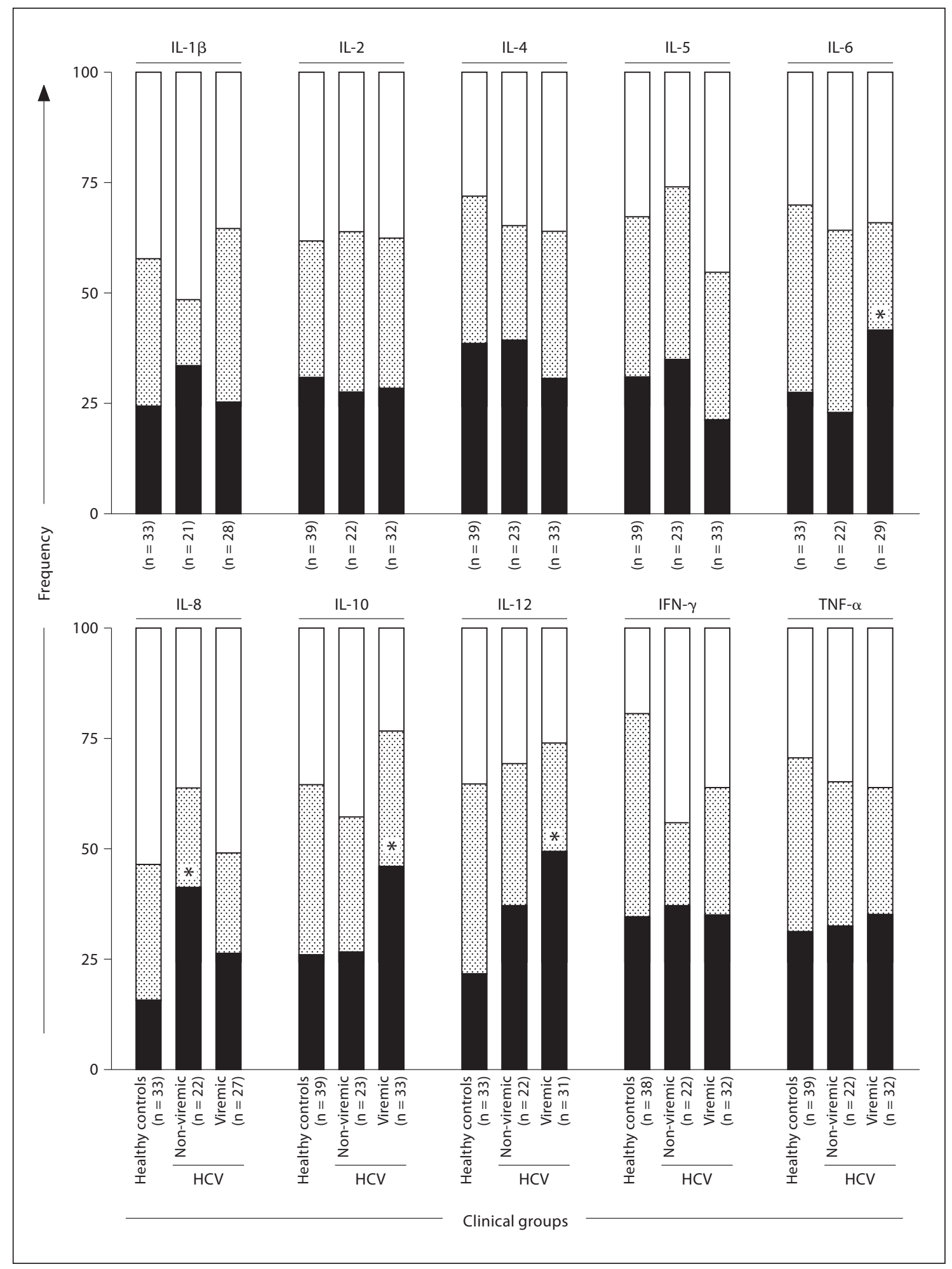

Fig. 2. Cytokine profile from non-viremic $(n=23)$ and viremic ( $\mathrm{n}=33) \mathrm{HCV}$-seropositive blood donors and healthy individuals (n = 39), categorized as low $(\square)$, medium (橉) or high ( $\square$ cytokine producers. Quantitative cytokine measurements were performed by CBA assay for IL-1 $\beta$, IL-2, IL-4, IL-5, IL-6, IL-8, IL-10,
IL-12, IFN- $\gamma$ and TNF- $\alpha$. The results are expressed as the frequency of each category within the non-viremic, viremic and healthy control groups. The statistical analysis was performed using a $\chi^{2}$ test. ${ }^{*}$ Significant differences were defined as $\mathrm{p}<0.05$ as compared to control. 


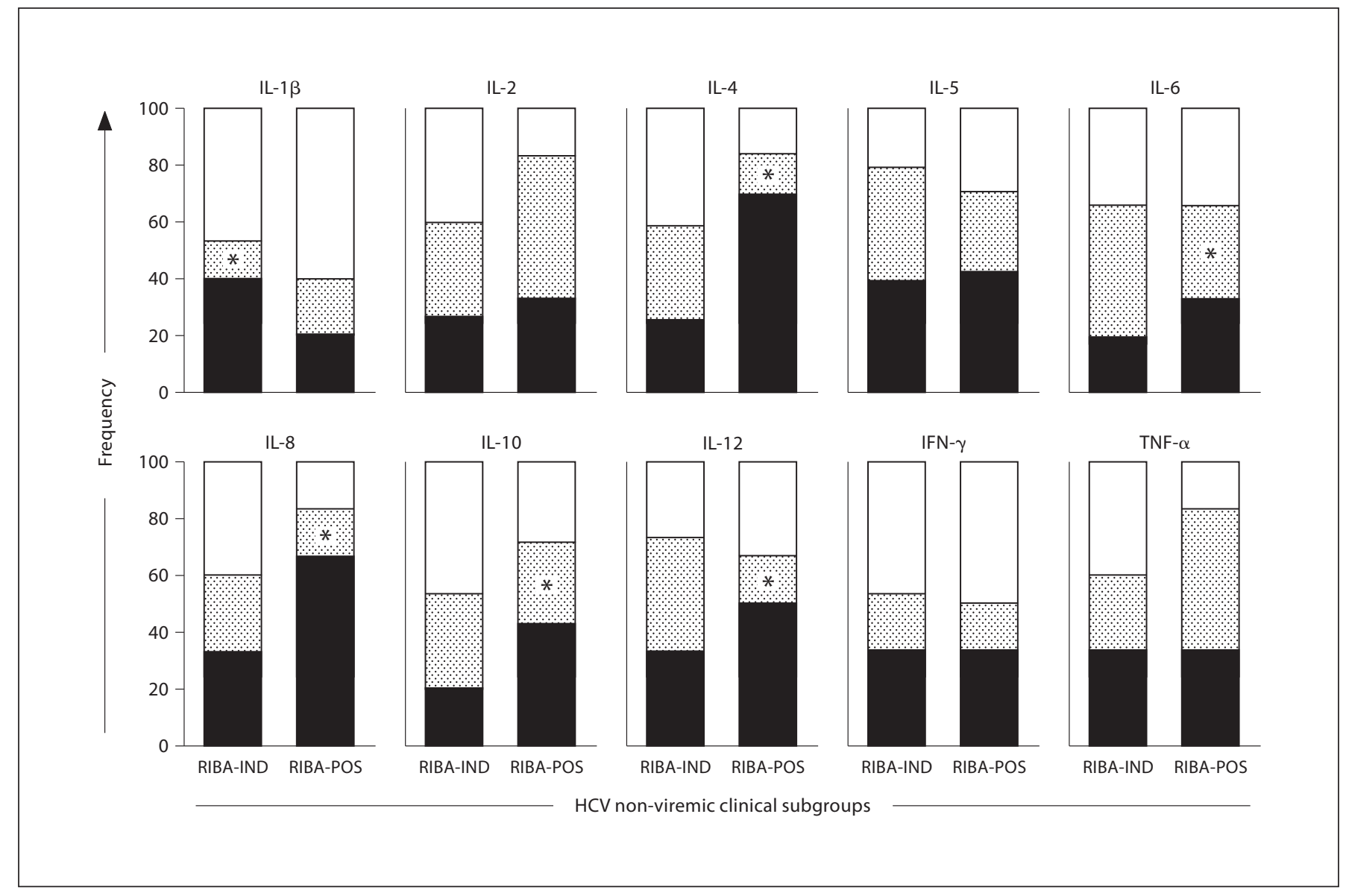

Fig. 3. Serum cytokine from non-viremic as low ( $\square$ ), medium (曽) or high ( $\square$ cytokine producer was categorized into two subgroups: RIBA-IND $(n=15)$ and RIBA-POS $(n=7)$ based on their RIBA test. Quantitative cytokine measurements were performed by CBA assay for IL-1 $\beta$, IL-2, IL-4, IL-5, IL-6, IL-8, IL-10, IL-12, IFN- $\gamma$ and TNF- $\alpha$. The results are expressed as the frequency for each of the non-viremic subgroups. Statistical analysis was performed by $\chi^{2}$ test. ${ }^{*}$ Significant differences at $\mathrm{p}<0.05$. test was used to compare the frequency of high cytokine producers among the clinical groups and subgroups. An analysis of the cytokine level between clinical subgroups was performed using the non-parametric Mann-Whitney test. The correlation analysis was performed using Spearman's test. In all tests, differences were considered significant if $\mathrm{p}<0.05$.

\section{Results}

\section{Cytokine Profiles of HCV-Seropositive Blood Donors}

Sera of blood donors were classified as low, medium or high cytokine producers by stratification into tertiles as follows: IL-1 $\beta$ (low $<1.4$, medium 1.4-3.2, high $>3.2 \mathrm{pg} /$ $\mathrm{ml}$ ); IL-2 (low $<2.6$, medium 2.6-3.1, high $>3.1 \mathrm{pg} / \mathrm{ml}$ ); IL-4 (low $<1.4$, medium $1.4-2.3$, high $>2.3 \mathrm{pg} / \mathrm{ml}$ ); IL-5 (low <1.6, medium 1.6-1.9, high $>1.9 \mathrm{pg} / \mathrm{ml}$ ); IL-6 (low $<1.1$, medium 1.1-1.9, high $>1.9 \mathrm{pg} / \mathrm{ml}$ ); IL-8 (low $<2.1$, medium 2.1-3.9, high $>3.9 \mathrm{pg} / \mathrm{ml}$ ); IL-10 (low $<1.5$, medium 1.5-1.9, high $>1.9 \mathrm{pg} / \mathrm{ml}$ ); IL-12 (low $<3.4$, medium 3.4-4.5, high $>4.5 \mathrm{pg} / \mathrm{ml}$ ); IFN- $\gamma$ (low <11.0, medium 11.0-17.8, high $>17.8 \mathrm{pg} / \mathrm{ml}$ ), and TNF- $\alpha$ (low $<1.3$, medium 1.3-1.9, high $>1.9 \mathrm{pg} / \mathrm{ml}$; fig. 1 ). The number of individuals for each cytokine varied according to the total number of samples tested (fig. 2). The data analysis demonstrated that high IL-1 $\beta$ and IL- 8 producers were selectively found in non-viremic subjects, whereas there was an increased frequency of high IL-6, IL-10 and IL-12 producers observed in viremic individuals compared to healthy controls (fig. 2). 


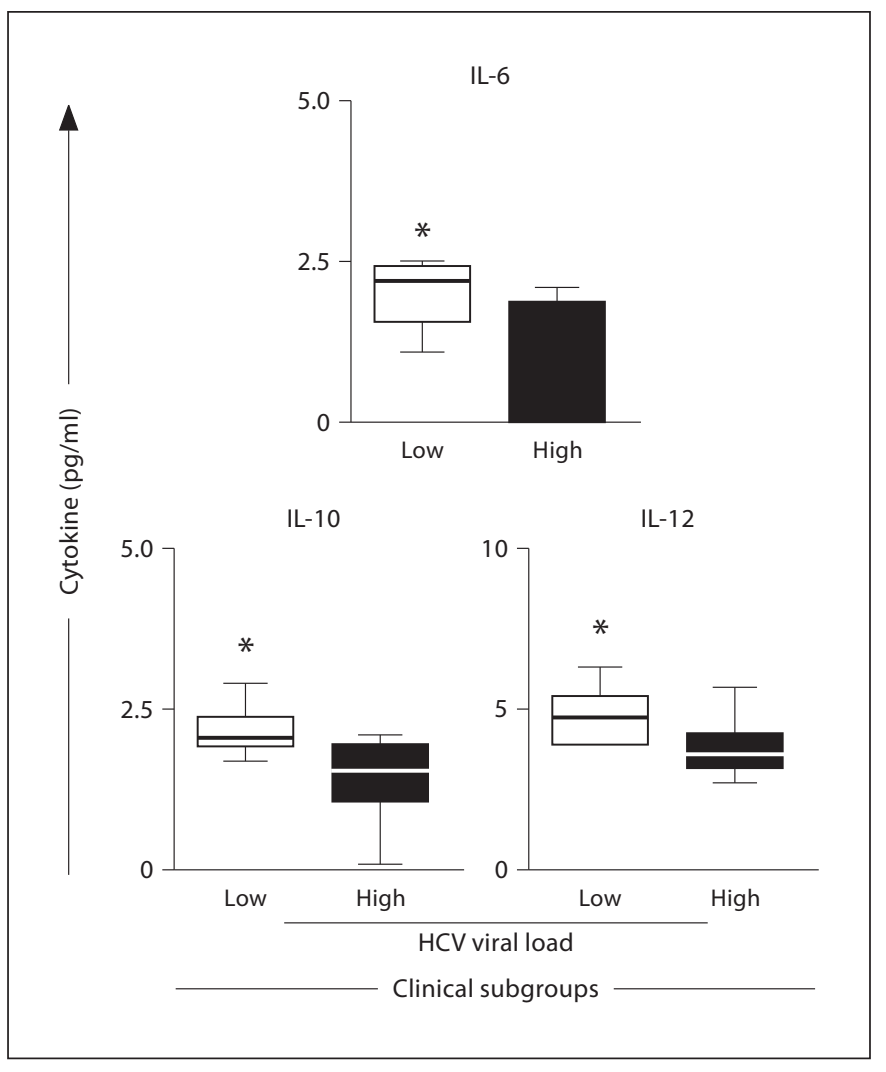

Fig. 4. Cytokine level in the viremic HCV-seropositive blood donors, categorized into two subgroups based on their HCV viral load referred to as low ( $\square$;n=7) or high ( $\square ; n=7)$, taking the median of $369,000 \mathrm{IU} / \mathrm{ml}$ as the cutoff to define the subgroups. Quantitative cytokine measurements were performed by CBA assay for IL-6, IL-10, and IL-12. The results are expressed as serum cytokine concentration $(\mathrm{pg} / \mathrm{ml})$ and data are presented in a box plot format. The boxes stretch from the lower hinge (defined as the 25 th percentile) to the upper hinge (75th percentile) and contain the middle half of the scores in the distribution. The median is shown as a line across the box. Statistical analysis was performed by non-parametric Mann-Whitney test. * Significant differences at $\mathrm{p}<0.05$ with the viremic group with high $\mathrm{HCV}$ viral load in comparisons between groups.

\section{Association between the Cytokine Profile and RIBA Reactivity}

The frequency of low-, medium- or high-cytokine producers was further addressed within the non-viremic group based on the RIBA. The subjects were classified as either RIBA-IND or RIBA-POS. The data analysis demonstrated that an increased frequency of high IL-1 $\beta$ producers was associated with the RIBA-IND subgroup while a large frequency of high IL-8 producers was observed in the RIBA-POS subgroup (fig. 3). Additionally, the RIBA-POS subgroup contained more high IL-4 pro- ducers. Moreover, high IL-6, IL-10 and IL-12 producers were observed in the RIBA-POS subgroup (fig. 3), similar to that observed in the viremic group (fig. 2).

\section{Increased Levels of IL-6, IL-10 and IL-12 in Blood Donors with a Low HCV Viral Load}

The cytokine levels in the serum samples from the viremic group were further evaluated to identify a possible association with the viral load. For this purpose, the viremic group was categorized into 2 subgroups: low and high HCV viral load. The data analysis demonstrated that all cytokines initially observed in the viremic group (fig. 2) were selectively enhanced in the subgroup with a low HCV viral load (fig. 4): IL-6 ( $\mathrm{p}=0.02)$, IL-10 ( $\mathrm{p}=0.04)$ and IL-12 $(\mathrm{p}=0.04)$. No significant differences were observed when the other cytokines were evaluated (data not shown).

\section{Association between Cytokine Profile and Serum ALT Level}

An additional analysis was performed in order to determine the association between the serum ALT levels, a liver injury biomarker, and the serum level of the inflammatory and regulatory cytokines. Subgroups of viremic subjects were then categorized as having low or high ALT levels. The median serum concentration of ALT in the viremic group $(46 \mathrm{IU} / \mathrm{ml})$ was used as the cutoff to differentiate between subgroups. A significantly increased level of TNF- $\alpha(\mathrm{p}=0.048)$, IL-1 $\beta(\mathrm{p}=0.03)$ and IL-8 ( $\mathrm{p}=$ 0.03 ) in the viremic group with a low ALT level is demonstrated in figure $5 \mathrm{a}$, similar to that observed in the nonviremic group (fig. 2). On the other hand, an increased level of IL-2 ( $\mathrm{p}=0.02)$ and IFN- $\gamma(\mathrm{p}=0.02)$ was observed in subjects with a high ALT level (fig. 5a).

In order to confirm our findings, an additional correlation analysis between the cytokine levels and the ALT levels was carried out. The data analysis demonstrated that while a negative correlation was observed between the ALT level and the IL- $1 \beta(\mathrm{p}=0.006, \mathrm{r}=-0.6558)$, IL-8 $(\mathrm{p}=0.02, \mathrm{r}=-0.5473)$ and TNF- $\alpha(\mathrm{p}=0.04, \mathrm{r}=-0.5031)$ levels, a positive correlation was found between the ALT level and the IL-2 ( $\mathrm{p}=0.03, \mathrm{r}=0.5253)$ and IFN- $\gamma(\mathrm{p}=$ $0.044, r=0.4938$ ) levels (fig. 5b).

\section{Discussion}

The precise role of the immune response in patients with HCV infection, in particular the relationship between the levels of inflammatory/regulatory cytokines 
Fig. 5. Cytokine levels in the viremic HCVseropositive blood donors, based on their serum ALT level: low $(\square ; \mathrm{n}=10)$ and high $(\square ; n=10)$, using the median serum concentration of ALT in the viremic group (46 $\mathrm{IU} / \mathrm{ml}$ ) as the cutoff to segregate the subgroups. a Quantitative cytokine measurements were performed by CBA assay for IL-1 $\beta$, IL-2, IL-8, IFN- $\gamma$ and TNF- $\alpha$. The results are expressed as the serum cytokine concentration $(\mathrm{pg} / \mathrm{ml})$ for each viremic subgroup. The data are present in box plot format, with the box stretching from the lower hinge (defined as the 25th percentile) to the upper hinge (75th percentile) and containing the middle half of the scores in the distribution. The median is shown as a line across the box. Statistical analysis was performed by non-parametric Mann-Whitney test. Significant differences were defined as $\mathrm{p}<0.05$ and the connecting lines indicate comparisons between the different groups. b A correlation analysis between the cytokine level and the serum ALT level was performed by non-parametric Spearman's test. The correlation indices ( $r$ and $p$ values) are shown.
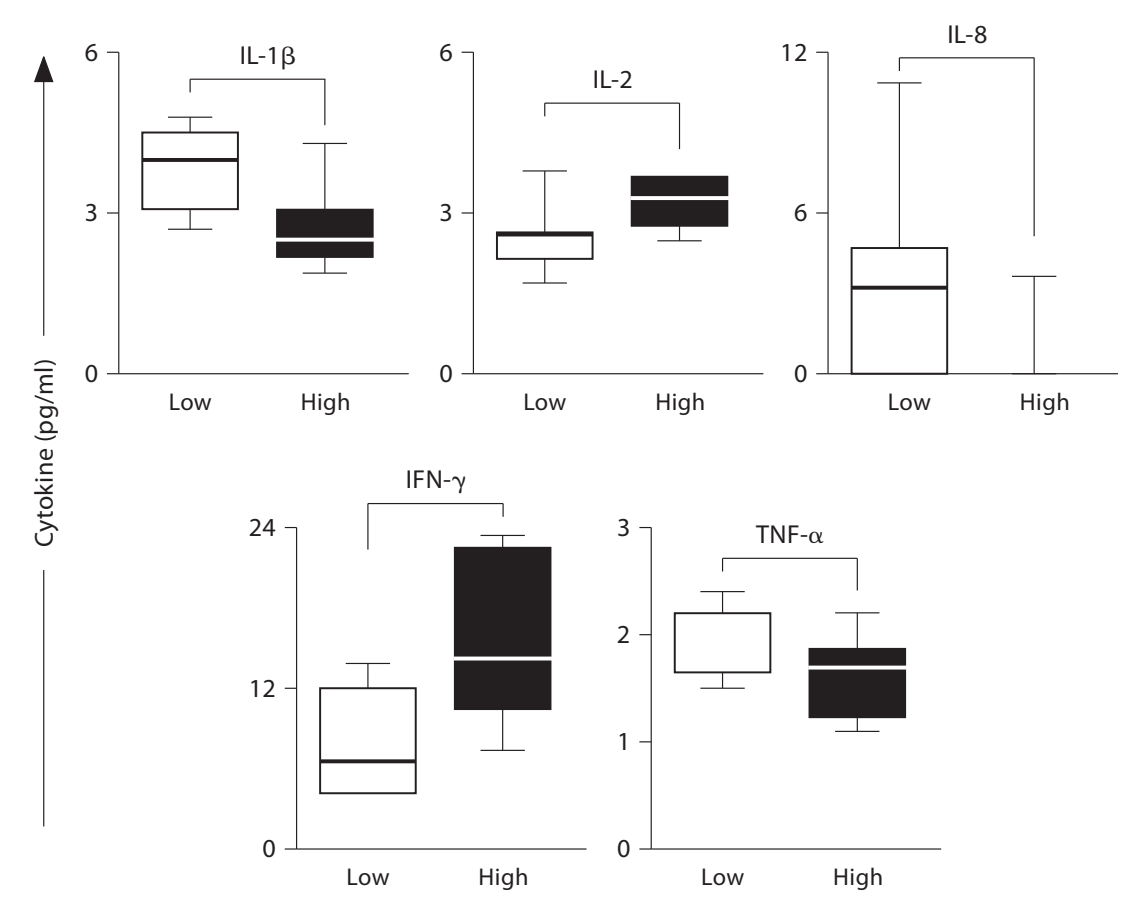

a

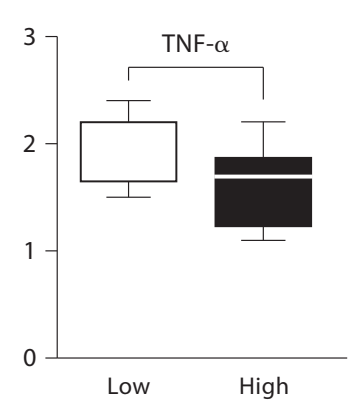

ALT

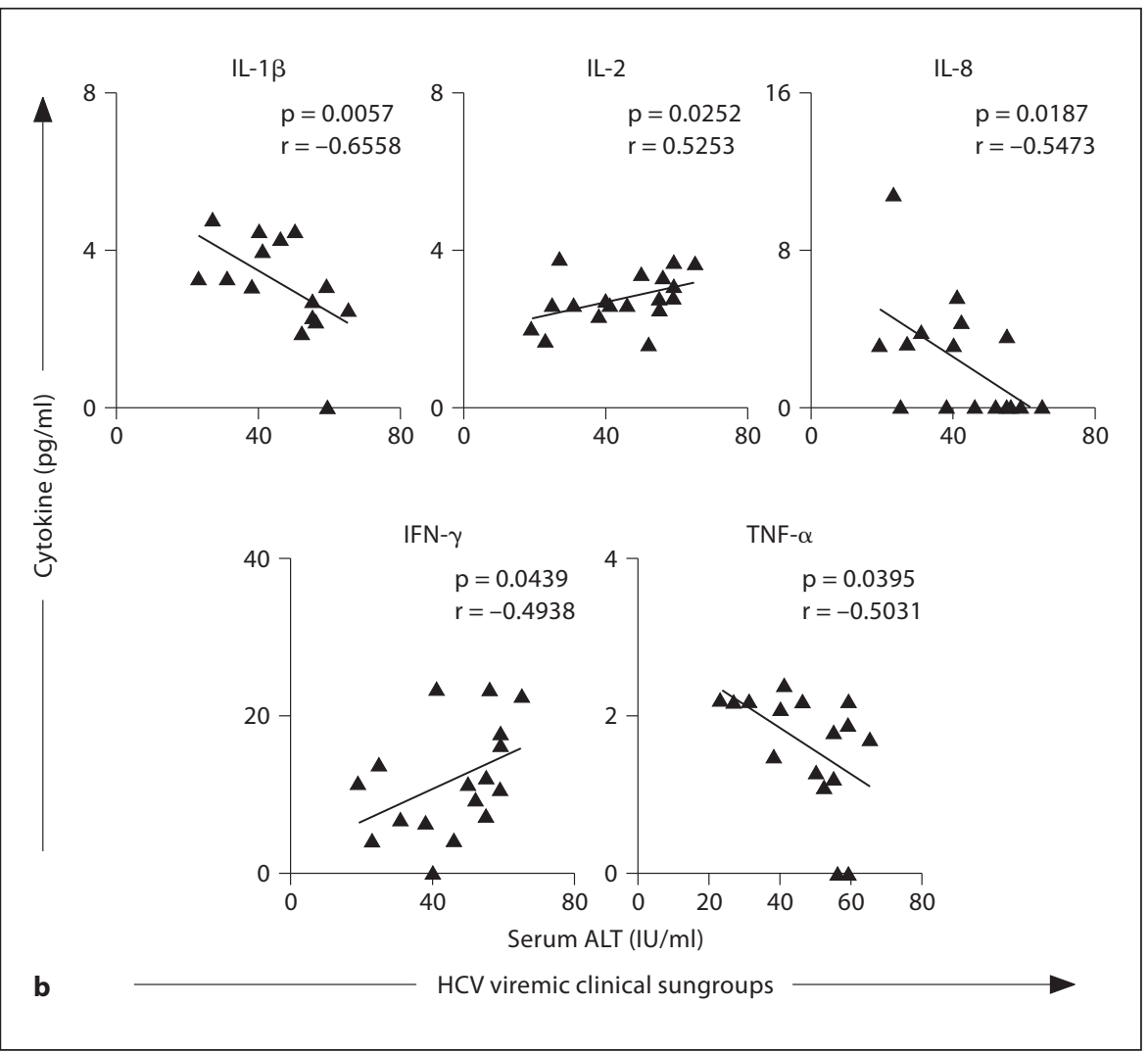


and the course of HCV infection, is still unclear. Recent work has suggested that these cytokines can trigger distinct patterns of protective or immunopathological responses and that they are involved in the clearance or establishment of chronic HCV infection [12].

It has been demonstrated that after spontaneous resolution of HCV infection, specific T-cell responses are maintained, while antibodies progressively decline and eventually disappear decades after exposure [13]. This probably explains why some seronegative individuals still display detectable HCV-specific cellular immune responses [14]. It has been suggested that changes in the level of proinflammatory and anti-inflammatory cytokines in the serum of HCV patients may be of significant diagnostic and prognostic importance [15]. As cytokines are important biomarkers that are associated with distinct profiles of the immune response, in the present investigation we explored the hypothesis that there is a distinct pattern of pro- and anti-inflammatory serum cytokines in HCV-seropositive blood donors that could be associated with their virological, laboratory, or disease phenotype, including viral load, HCV-RIBA profile and ALT serum level.

To eliminate the false-positive EIA results $[16,17]$, usually found in low-risk populations such as blood donors, the samples were screened by RIBA. Several strategies have been used to clarify the significance of the RIBA-IND result in the absence of serum HCV-RNA, including the analysis of risk factors, the ALT level, the sample to cutoff ratio in the screening test, prior donation history, the intensity of single band reactivity of the confirmatory immunoblot assay [18] and the use of synthetic peptides and/or anti-E2, ELISpot assays [19-22]. This suggests that such donors had been exposed to the virus and that their antibody reactivity was a footprint of recovery from infection. The magnitude of the T-cell response among RIBA-IND individuals was similar to that of RIBA-POS blood donors for the Core and NS3 antigens, and therefore, cytokine analysis might be a useful complementary tool in the diagnosis of $\mathrm{HCV}$ infection in these individuals [23]. Currently, cases of non-viremic RIBA-IND individuals are not investigated any further. However, it should be considered that RIBA-IND results may represent early seroconversion, even in the absence of detectable HCV-RNA [8].

Our data demonstrated that high IL-1 $\beta$ producers were more frequent among the non-viremic RIBA-IND blood donors, while there was an increased frequency of high IL-8 producers in the RIBA-POS blood donors. A few studies have been performed to investigate the asso- ciation between the level of IL- $1 \beta$ and the clinical status of HCV infection. However, it was demonstrated that IL$1 \beta$ production was impaired in patients with chronic HCV infection, suggesting that IL- $1 \beta$ may play a role in viral clearance. Using an HCV subgenomic replicon cell line, it has been demonstrated that IL-1 $\beta$ can effectively inhibit the replication of HCV-RNA and viral protein expression, suggesting that IL- $1 \beta$ has direct antiviral activity [24]. Conversely, it has been demonstrated that HCVinfected patients with detectable anti-NS5-specific antibodies had significantly higher IL-1 $\beta$ levels than HCV patients without anti-NS5-specific antibodies [15]. The presence of anti-NS5-specific antibodies has been previously recognized as a putative biomarker of moderate and high hepatitis C reactivity [25], as well as an indicator of poor therapeutic response [26]. Therefore, the increased level of IL-1 $\beta$ in patients with anti-NS5-specific antibodies would suggest the opposite role for IL-1 $\beta$ in contrast to what has been proposed previously [24]. Additionally, it has been shown that there was no significant difference in the IL- $1 \beta$ polymorphisms found in individuals who cleared HCV and those who did not [27]. These findings indicate that further studies are necessary to clarify the precise role of IL-1 $\beta$ in the pathogenesis of $\mathrm{HCV}$ infection.

IL-8 has been described in chronic HCV infection, and it has been reported to reduce the antiviral activity of IFN- $\alpha[28,29]$. This could lead to HCV persistence and explain the higher frequency of high IL-8 producers in the RIBA-POS blood donors. Furthermore, Balasubramanian et al. [30] suggested that HCV proteins triggered the release of inflammatory chemokines such IL-8 and caused endothelial apoptosis, thereby facilitating endothelitis. In addition, IL-8 was positively associated with HCV chronic replication [31] and correlated with histopathological alterations in the liver [32]. However, the precise role of IL-8 and its association with the clinical features of $\mathrm{HCV}$, including viral clearance, are inconsistent and require further investigation.

Interestingly, our data demonstrated an increased frequency of IL-6, IL-10 and IL-12 producers in RIBA-POS blood donors, similar to that observed in the viremic group. The increased frequency of high IL- 6 and IL-10 producers in these subjects is similar to reports examining chronically infected HCV patients [33, 34]. Since cytokine genes are polymorphic, and certain mutations located within coding/regulatory regions have been shown to affect the overall expression and secretion of cytokines, there may be a correlation between cytokine gene polymorphisms and their association with the outcome 
of HCV infection. It has been demonstrated that a significant proportion of patients who cleared HCV have a low IL-6 production profile, whereas those with persistent infection were found to have a high production profile [35]. These data are in agreement with the increased frequency of high IL-6 producers that was observed in the RIBA-POS non-viremic group and the viremic subgroup. It has been demonstrated that during chronic HCV infection, antigen-specific cytokine production by monocytes shifted predominantly towards IL-10 production, which may contribute to persistent viral replication [36]. This is in agreement with the increased frequency of high IL-10 producers that we observed in the viremic subgroup, but was inconsistent with the higher frequency of high IL-10 producers among the subjects with a lower viral load.

In the current study, the cytokine levels in serum samples from the viremic group were evaluated in order to investigate a possible association with either the viral loads or the serum ALT levels. We did not study the impact of HCV genotype on cytokine levels because the majority of the patients were infected with HCV genotype 1 (table 1). In addition, in an analysis of gender and cytokine levels we did not find any significant differences (data not shown). Our data demonstrated that all of the cytokines that were detected in the viremic group (IL-6, IL-10 and IL-12; fig. 4) were selectively enhanced in the subgroup with low HCV viral load. Additionally, the high
IL-1 $\beta$, IL- 8 and TNF- $\alpha$ producers were more frequently found in the viremic group with a low ALT level, while the high IL-2 and IFN- $\gamma$ producers were selectively increased in subjects with a high ALT level (fig. 5a). These results suggest that the proinflammatory cytokines IL$1 \beta$, IL- 8 and TNF- $\alpha$, which are predominantly related to the innate immune response, were more likely to be associated with an initial or less severe $\mathrm{HCV}$ infection, whereas IL-2 and IFN- $\gamma$, which are largely involved with the adaptive immune response, were more often linked to the ALT serum level, a biomarker of liver injury (fig. 5b).

Taken together, our findings suggest that serum cytokines might be a complementary tool to decode the clinical status of HCV-seropositive blood donors and aid in counseling and disease management.

\section{Acknowledgements}

This work was supported by the National Council for Scientific Development and Technology (CNPq, grant No. 304713/20002-3; 403071/2004-6), the Support Program for Centers of Excellence (PRONEX- 08282/07) and the Bahia State Foundation for the Support of Research (FAPESB, grant No. 040262). Thank the CNPq for the Research fellowship (PQ). We would like to thank Geruza Maria Carneiro Morais from LACEN for laboratory support, and Alan McBride for critical review of the manuscript.

\section{References}

1 Global Burden of Hepatitis C Working Group: Global burden of disease (GBD) for hepatitis C. J Clin Pharmacol 2004;44:20-29.

-2 Caruntu FA, Benea L: Acute hepatitis C virus infection: diagnosis, pathogenesis, treatment. J Gastrointestin Liver Dis 2006;15: 249-256.

- 3 Pham TN, MacParland SA, Mulrooney PM, Cooksley H, Naoumov NV, Michalak TI: Hepatitis $\mathrm{C}$ virus persistence after spontaneous or treatment-induced resolution of hepatitis C. J Virol 2004;78:5867-5874.

4 Thomson BJ, Finch RG: Hepatitis C virus infection. Clin Microbiol Infect 2005;11:8694.

5 Gremion C, Cerny A: Hepatitis C virus and the immune system: a concise review. Rev Med Virol 2005; 15:235-268.

-6 Guobuzaite A, Chokshi S, Balciuniene L, Voinic A, Stikleryte A, Zagminas K, Ambrozaitis A, Naoumov N: Viral clearance or persistence after acute hepatitis $\mathrm{C}$ infection: interim results from a prospective study. Medicina (Kaunas) 2008;44:510-520.
7 Gigi E, Raptopoulou-Gigi M, Kalogeridis A, Masiou S, Orphanou E, Vrettou E, Lalla TH, Sinakos E, Tsapas V: Cytokine mRNA expression in hepatitis $\mathrm{C}$ virus infection: TH1 predominance in patients with chronic hepatitis $\mathrm{C}$ and TH1-TH2 cytokine profile in subjects with self-limited disease. J Viral Hepat 2008; 15:145-154.

8 Lavillette D, Morice Y, Germanidis G, Donot P, Soulier A, Pagkalos E, Sakellariou G, Intrator L, Bartosch B, Pawlotsky JM, Cosset FL: Human serum facilitates hepatitis C virus infection, and neutralizing responses inversely correlate with viral replication kinetics at the acute phase of hepatitis $C$ virus infection. J Virol 2005;79:6023-6034.

9 Chevaliez S, Pawlotsky JM: Hepatitis C virus: virology, diagnosis and management of antiviral therapy. World J Gastroenterol 2007;13:2461-2466.

10 Chan SW, McOmish F, Holmes EC, Dow B, Peutherer JF, Follett E, Yap PL, Simmonds P: Analysis of a new hepatitis $C$ virus type and its phylogenetic relationship to existing variants. J Gen Virol 1992;73:1131-1141.
11 Cook EB, Stahl JL, Lowe L, Chen R, Morgan E, Wilson J, Varro R, Chan A, Graziano FM, Barney NP: Simultaneous measurement of six cytokines in a single sample of human tears using microparticle-based flow cytometry: allergics vs. non-allergics. J Immunol Methods 2001;254:109-118.

12 Hiroishi K, Ito T, Imawari M: Immune responses in hepatitis $\mathrm{C}$ virus infection and mechanisms of hepatitis $C$ virus persistence. J Gastroenterol Hepatol 2008;23:1473-1482.

13 Takaki A, Wiese M, Maertens G, Depla E, Seifert U, Liebetrau A, Miller JL, Manns MP, Rehermann B: Cellular immune responses persist and humoral responses decrease two decades after recovery from a single-source outbreak of hepatitis C. Nat Med 2000;6: 578-582.

14 Kamal SM, Amin A, Madwar M, Graham CS, He Q, Al Tawil A, Rasenack J, Nakano T, Robertson B, Ismail A, Koziel MJ: Cellular immune responses in seronegative sexual contacts of acute hepatitis C patients. J Virol 2004;78:12252-12258 
-15 Krasavtsev EL, Mitsura VM, Zhavoronok SV: Levels of some cytokines and antibodies to hepatitis $\mathrm{C}$ virus in patients with chronic hepatitis C (in Russian). Zh Mikrobiol Epidemiol Immunobiol 2005;5:103-105.

- 16 Alter MJ, Kruszon-Moran D, Nainan OV, McQuillan GM, Gao F, Moyer LA, Kaslow RA, Margolis HS: The prevalence of hepatitis $\mathrm{C}$ virus infection in the United States, 1988 through 1994. N Engl J Med 1999;341:556562 .

- 17 Krajden M: Hepatitis C virus diagnosis and testing. Can J Public Health 2000;91(suppl 1):S34-S42.

18 Kiely P, Kay D, Parker S, Piscitelli L: The significance of third-generation HCV RIBAindeterminate, RNA-negative results in voluntary blood donors screened with sequential third-generation immunoassays. Transfusion 2004;44:349-358

-19 Tobler LH, Busch MP, Wilber J, Dinello R, Quan S, Polito A, Kochesky R, Bahl C, Nelles M, Lee SR: Evaluation of indeterminate c223 reactivity in volunteer blood donors. Transfusion 1994;34:130-134.

-20 León P, López JA, Elola C, Domingo CJ, Echevarria JM: Detection of antibody to hepatitis $\mathrm{C}$ virus $\mathrm{E} 2$ recombinant antigen among samples indeterminate for anti-HCV after wide serological testing and correlation with viremia. The Spanish Study Group for Blood Donors at Risk of Transmission of HCV. Vox Sang 1996;70:213-216.

-21 León P, López JA, Elola C, Lee SR, Calmann M, Echevarria JM: Use of overlapping synthetic peptides to characterize samples from blood donors with indeterminate results to hepatitis C virus core antigen. Vox Sang 1998;75:32-36.
22 Semmo N, Barnes E, Taylor C, Kurtz J, Harcourt G, Smith N, Klenerman P: T-cell responses and previous exposure to hepatitis $\mathrm{C}$ virus in indeterminate blood donors. Lancet 2005;365:327-329.

23 Bes M, Esteban JI, Casamitjana N, Piron M, Quer J, Cubero M, Puig L, Guardia J, Sauleda S: Hepatitis C virus (HCV)-specific t-cell responses among recombinant immunoblot assay-3-indeterminate blood donors: a confirmatory evidence of HCV exposure. Transfusion 2009;49:1296-1305.

24 Zhu H, Liu C: Interleukin-1 inhibits hepatitis $\mathrm{C}$ virus subgenomic RNA replication by activation of extracellular regulated kinase pathway. J Virol 2003;77:5493-5498.

25 Krasavtsev EL, Zhavoronok SV, Mitsura VM, Demchilo AP: Antibodies to different virus antigens in patients with chronic hepatitis C (in Russian). Zh Mikrobiol Epidemiol Immunobiol 2006;2:57-61.

26 Garrido A, Lepe JA, Guerrero FJ, Palomo S: Serologic response against hepatitis $\mathrm{C}$ virus as a predictive factor to the treatment with interferon (in Spanish). Enferm Infecc Microbiol Clin 2000;18:512-515.

27 Minton EJ, Smillie D, Smith P, Shipley S, McKendrick MW, Gleeson DC, Underwood JC, Cannings C, Wilson AG: Clearance of hepatitis $\mathrm{C}$ virus is not associated with single nucleotide polymorphisms in the IL-1, -6 , or -10 genes. Human Immunol 2005;66:127132.

28 Polyak SJ, Khabar KS, Rezeiq M, Gretch DR: Elevated levels of interleukin-8 in serum are associated with hepatitis $\mathrm{C}$ virus infection and resistance to interferon therapy. J Virol 2001;75:6209-6211.

29 Wertheimer AM, Polyak SJ, Leistikow R, Rosen HR: Engulfment of apoptotic cells expressing HCV proteins leads to differential chemokine expression and stat signaling in human dendritic cells. Hepatology 2007;45: 1422-1432.
30 Balasubramanian A, Munshi N, Koziel MJ, Hu Z, Liang TJ, Groopman JE, Ganju RK: Structural proteins of hepatitis $C$ virus induce interleukin 8 production and apoptosis in human endothelial cells. J Gen Virol 2005; 86:3291-3301.

31 Chang LY, Wan HC, Lai YL, Liu TY, Hung SL: Enhancing effects of areca nut extracts on the production of interleukin- 6 and interleukin- 8 by peripheral blood mononuclear cells. J Periodontol 2006;77:1969-1977.

-32 Avramescu CS, Comanescu V, Popescu SN, Turculeanu A, Balasoiu M, Popescu CF, Lungulescu M: Correlations among the serum levels of some interleukins and the histopathological aspects in chronic viral hepatitis C. Rom J Morphol Embryol 2008;49:5762 .

33 Abayli B, Canataroglu A, Akkiz H: Serum profile of $\mathrm{t}$ helper 1 and $\mathrm{t}$ helper 2 cytokines in patients with chronic hepatitis $\mathrm{C}$ virus infection. Turk J Gastroenterol 2003;14:7-11.

34 Zekri AR, Ashour MS, Hassan A, Alam ElDin HM, El-Shehaby AM, Abu-Shady MA: Cytokine profile in Egyptian hepatitis $\mathrm{C}$ virus genotype-4 in relation to liver disease progression. World J Gastroenterol 2005;11: 6624-6630

35 Barrett S, Collins M, Kenny C, Ryan E, Keane CO, Crowe J: Polymorphisms in tumour necrosis factor-alpha, transforming growth factor-beta, interleukin-10, interleukin-6, interferon-gamma, and outcome of hepatitis C virus infection. J Med Virol 2003; 71:212-218.

-36 Woitas RP, Petersen U, Moshage D, Brackmann HH, Matz B, Sauerbruch T, Spengler $\mathrm{U}$ : HCV-specific cytokine induction in monocytes of patients with different outcomes of hepatitis C. World J Gastroenterol 2002;8:562-566. 